INTERNATIONAL JOURNAL OF RESEARCHES IN BIOSCIENCES, AGRICULTURE AND TECHNOLOGY (C) VISHWASHANTI MULTIPURPOSE SOCIETY (Global Peace Multipurpose Society) R. No. MH-659/13(N) www.vmsindia.org

\title{
INDUCED RESISTANCE AGAINST LEAF BLIGHT PATHOGEN HELMINTHOSPORIUM TURCICUM IN PROTECTING JAWAR SEEDLINGS BY SEED TREATMENT
}

\author{
M. N. Bhajbhuje \\ Jawaharlal Nehru Mahavidyalaya, Wadi, Nagpur \\ dr_mnbhajbhuje@rediffmail.com
}

\begin{abstract}
:
The leaf spot causing pathogenic organism of fungal origin reduce quality and productivity of crop plants. A hybrid variety of Jawar is susceptible to fungal attack causing leaf spot disease. The resistance to pathogen is induced in young seedlings with seed treatment of abiotic elicitors. The Jawar seedling raised from treated seeds with dilute solution of chemicals were inoculated by spraying foliage with conidial suspension of Helminthosporium turcicum Pass and assayed for number and size of lesions on leaves at different intervals. Most of the chemicals, when used to soak seeds, induce resistance to 14-days-old susceptible Jawar seedlings against inoculation with Helminthosporium turcicum The disease index was very significantly reduced as well as lesion expansion was inhibited in plants receiving chemical seed treatment. Resistance effect persisted at significant levels even in 28days-old plants. In vitro studies on fungitoxicity of leaf diffusate of treated plants on spore germination of $H$. turcicum indicates that different treatments lead to the development of moderate to high level of fungitoxicity in young seedlings. Treated young seedlings developed higher fungitoxicity over controls. Fungitoxicity gradually declined with age of plant and disappeared in 28-days-old plants. Studies on direct effect of these treatments reveals that chlorides of mercury, copper, cadmium totally inhibited fungal spore germination while other compound had only mild to moderate inhibitory effect.
\end{abstract}

Keyw ords: Fungitoxicity, susceptible, abiotic elicitors, Helminthosporium turcicum, induced

\section{Introduction:}

Sorghum vulgare L. (Jawar) is a principle food crop belonging to family Poaceae that can thrive in warm climate worldwide with little rainfall providing nutrients for millions of people (Wikipedia, 2015). The small, round and white caryopsis is store house of carbohydrate, protein, minerals and B-complex vitamins hence used for bread making, food for domesticated animals and also in brewing industries. Leaves are an additional source of food nutrients and phytochemicals with antioxidant properties which hold promise as source of food and herbal medicine in the developing world (Lucy and Ifedayo, 2012). Some chemical compounds of seeds are confined protective against cancer, heart disease, heavy menstrual flow, and tumor growth. It contains no gluten which makes it an excellent nutrient source for individuals with celiac disease (FAO, 2014). It ranks fifth most important cereal crop grown on the globe. USA rank first in Sorghum production in the World with 9.8 million tons output followed by Mexico with 7.3 million tons output. India realized 5.5 million tons in 2013/14 season (Wikipedia, 2015).

The leaf spots may be control by foliar application of effective organic fungicides, but these are reported hazardous and their residual toxicity in plant parts, fruits poses carcinogenic disorders to consumers (Trivedi, et al., 1963) and also helps to increase level of air pollutants. To overcome these, the concept of screening for disease resistance has been developed (Eckadt,
2011). Phytoalexin accumulation at infection site in leaves, stem, cotyledons and hypocotyl (Ingham, 1982), in response to wounding (Rahe and Arnold, 1975), to interaction with microorganism (Iriti \& Franco, 2009) or to treatment with certain chemicals (Darvill and Albershiem, 1984) makes a significant contribution to resistance, cultivars that are normally susceptible to a virulent race of pathogen thus providing protection in different plants

The seed treatment with phytoalexin inducer chemicals induced most effective protection to plants against pathogen and proved effective method in seed producing plants has been successfully demonstrated in chestnut (Dierauf, et al., 1997) and in tomato (Bhajbhuje, 2013). After seed treatment, the susceptible plants become activated and these produced, when inoculated, much larger amount of fungitoxic substances that inhibited symptoms expression. Lucy and Ifedayo (2012) reported role of antifungal phytochemicals in varietal specific resistance of Sorghum to leaf blight pathogen. Presently specific phytoalexin type substance has so far not been reported from Sorghum plants in response to infection of virulent strain of Helminthosporium turcicum, it seemed to be worthwhile to study this phenomenon with the SorghumHelminthosporium turcicum model.

\section{Materials and Methods:}

Plant material and chemicals: Jowar (Sorghum vulgare L.) is used as experimental material. The 
fungitoxicity of an aqueous solution in dilute concentration $\left(10^{-2}\right.$ to $\left.10^{-5} \mathrm{M}\right)$ of six salts of heavy metal of diverse nature was assayed for their toxic response on spore germination of Helminthosporium turcicum (CIM, 2010). The conc. $\left(10^{-4} \mathrm{M}\right)$ was seemed to be most effective in inhibition of spore germination and germ tube growth, was selected for further treatment.

Seed treatment: Seeds soaked for 24 hour in test solution $\left(10^{-4} \mathrm{M}\right)$ were being sown in sterile soil supplemented with FYM in $16 \mathrm{~cm}$ earthen pots. The pots were maintained in laboratory at $16-28^{\circ} \mathrm{C}$, where sufficient light is available and watered daily.

Inoculation: The seedlings in different treatments raised from treated or untreated seeds were inoculated at the age of 3-week by spraying foliage with the conidial suspension of 6 days old culture of test fungus in water till run-off. Controls were sprayed with water. To facilitate infection, pots with plants were covered with polythene and kept for $24 \mathrm{hrs}$ in a humid chamber.

Disease assessment: Symptoms appeared on the leaves were assayed a week after inoculation and disease index was computed. Leaf diffusates obtained 3 days after inoculation from both uninoculated and inoculated seedling were assayed for their effect on the spore germination of test pathogen employing standard method (CMI, 2010).

\section{Results and Discussion:}

Six heavy metal salts were screened to study the parameters. Initially, in vitro fungitoxicity of test chemicals was assayed and results are described as under.

\section{In-vitro fungitoxicity of test chemicals:}

An aqueous solution of chlorides of mercury and copper and cadmium caused injury to spore Helminthosporium turcicum at low conc. (10-4) and induced total inhibition of spore germination and germ tube growth. Lithium sulphate, chlorides of ferrous and barium caused considerable inhibition at $10^{-4} \mathrm{M}$ conc. reducing spore germination varied between 55 to $78 \%$ over control while moderate inhibitory effect (43 to 53\%) was recorded with all test chemicals at $10^{-5} \mathrm{M}$ conc. Similar trend was recorded for germ tube growth with all conc. of the test chemicals. Barium chloride at any of its two conc. did not induce significant inhibitory effect on spore germination. This report is in agreement with earlier finding of Bhajbhuje (2014) who reported inhibitory response of heavy metals on microbial community. Deepa and Padmaja (2013) confirmed effectiveness of chemicals on inhibition of spores of Helminthosporium. The chlorides of mercury, copper and cadmium are highly toxic over other test chemicals at very low conc. to spores of test pathogen.

Direct toxicity of heavy metal salts of varying origin to the fungal pathogen does not seem to explain the reduction of symptoms. Chlorides of ferrous and barium are non-toxic, provided stronger protection than mercuric, cadmium and cupric chloride, a highly toxic one. These test chemicals may exert inhibitory influence upon fungal spores germination and impose upon them exogenous dormancy. The inhibition of spore germination may be attributed to variable toxic effect of test chemicals. The hydrolytic products of the chemicals possibly at low conc. induced dormancy or may cause injuries to fungal spores by dissolving the protective thick seed coat and plasma membrane or ruptured them making porous.

\section{Effect of wet seed treatments on symptoms expression:}

The Seed soaking in aqueous solution of test chemicals seemed to be the most effective technique for most of the treatment induced 49$84 \%$ protective effect at 3 -wk stage. The inhibitory effect gradually declines in most of the treatment with age of plant except barium chloride. A greatest inhibition was recorded at 4 -wk growth stage to the extent of 48 to $74 \%$ in the seedling receiving seed treatment. The seed treatment provide substantial protection and long persistent of such effect at significant level (Table 1). These results are confirmed with earlier finding in Solanum melongena $\mathrm{L}$ (Bhajbhuje, 2013). The accumulation of phytoalexins in response to chemical seed treatment was reported in peanuts (Sobolev et al., 2007).

\section{Persistence of protective effect:}

All the test chemicals, when applied through wet seed treatment, effectively protected 2-wk-old seedlings against Helminthosporium leaf spot infection caused by $H$. turcicum. The most pronounced protective effect was recorded in seedlings receiving wet seed treatment when artificially inoculated at 3 -wk growth stage and the symptoms were assayed at the age of 5- 8 6wk growth stage. In most of the treatments, the pronounced protective effect was achieved to a significant level after artificial inoculation the seedlings by isolate of virulent pathogen. At the age of 5-wk, the greatest protective effect was recorded with chlorides of barium and mercury; considerable with cupric chloride while least 
with lithium sulphate. The most pronounced persistence of inhibitory effect was recorded with chlorides of barium and mercury followed by cupric chloride. Excluding ferric chloride, lithium sulphate and cadmium chloride, the considerable inhibitory effect was persisted in inoculated plants up to 6-wk stage (Table 2).

Moreover, the most pronounced effects being recorded with barium chloride reducing lesion number by $76 \%$ followed by chloride of mercury and copper while, other treatment had moderate protective effect while lesion expansion was inhibited in all cases; stronger inhibition was recorded with chlorides of barium, mercuric and cadmium. Reduction in number of infections in most of the treatments and inhibition of lesion expansion in some, suggesting that induced resistance may have operated at two stages i.e., initially by limiting the number of successful infection and subsequently by restricting lesion size. This may imply some post inflectional changes in leaf tissue in treated plants that may limit in vitro activity of the pathogen.

\section{Fungitoxicity of leaf diffusate:}

In the final experiment, the seedlings were raised in pots from soaked seeds and inoculated at the age of 3-wk. Leaf diffusates were obtained initially from 2 -wk old uninoculated plants and later from both uninoculated and inoculated plants in different treatments 3 days later each inoculation and bio-assayed for fungitoxicity (Table 2). Leaf diffusates collected from uninoculated plants in different treatments elicited supportive response to spore germination with very mild toxic effect. However, diffusates from comparable inoculated plants in all treatment induced significant levels of fungitoxicity, causing 64 to $82 \%$ spore inhibition compared to only $11 \%$ in control at 3wk stage. Most pronounced toxicity was recorded with chlorides of mercury, copper \& barium while a moderate toxicity was confined with lithium sulphate over control. The leaf diffusates from 4-wk-old inoculated plants was seemed to be comparatively less fungitoxic, causing $38-74 \%$ reduction in spore germination compared to only $9 \%$ reduction in control indicated fungitoxicity of leaf diffusates gradually declines with age of the plant. Similar trend was recorded for germ tube growth with conc. of test chemicals (Table 2).

Inoculation with compatible race of pathogen itself led to the development of considerable fungitoxicity in plants grown from untreated seeds. This seems to have resulted from production of antifungal compounds in the leaves themselves by plant during successive growth period. Lucy and Ifedayo (2012) reported some antifungals and phenol from leaves of Sorghum vulgare L., induced total inhibition of mycelial growth \& sporulation of indicating a defense response. Reduced fungitoxic effect of leaf diffusates on both spore germination and germ tube growth was recorded with all plants receiving treatment, when inoculated 3 days after 3-wk growth stage with spore suspension of Helminthosporium turcicum. The leaf diffusates from 3-wk old inoculated plants receiving treatment with chlorides of mercury and barium were reported comparatively effective, causing highest reduction in spore germination followed by cupric chloride while others had moderate inhibitory effect. The leaf diffusates from plants receiving these treatments were highly toxic to pathogen, reducing $63-82 \%$ germ tube growth. A fungitoxicity was gradually decline with age of plants. A leaf diffusates of 4-wk-old inoculated plants receiving seed treatment with all chlorides except cadmium chloride and lithium sulphate was reported considerably toxic to pathogen, while other treatments induced moderate toxicity for these parameters (Table 2).

Significant to moderate levels of fungitoxicity was recorded in the leaf diffusates from 3-wk-old uninoculated seedlings in different treatment while considerable to mild toxicity was observed from 4-wk-old seedlings receiving treatment with chlorides of mercury, barium and copper while mild toxicity was recorded with others treatments. The fungitoxicity rapidly declined with plants age and disappear between 5-6-wk in most of the treatments. It is possible that the substance was metabolized and also diluted by plant growth so as to leave moderate toxic effect at the 4-wk stage. The untreated (control) plants themselves developed considerable, $7-13 \%$ fungitoxicity when inoculated after 3- or 4-wk. The greater post-infection development of fungitoxicity in treated plants, even 4-wk, after seed treatment, appears to be more significant than the initial development of toxicity in them. This seems to have resulted from the interaction between seed treatment \& infection, mediated possibly through some alteration in host metabolism. These results are confirmed with earlier reports as in Peanut (Sobolev et al., 2007); Cicer arietinum L (Raju et al, 2008); Fragaria vesca (Amil-Ruiz, et al., 2011). Bhajbhuje(2014) reported similar finding while studying role of phytoalexin inducer chemical in Vigna mungo L 
The results obtained in the present investigation reveals that in vitro, chlorides of mercury, copper and cadmium inhibited total spore germination and germ tube growth but allow mild lesion formation in 5-6-wk old plants. At this stage of growth, moderate toxicity was evident in leaf diffusate of plants from any treatment. This may suggests that some quantity fungitoxic substance was produced in Sorghum in response to seed treatment. Little symptoms were produced when the production of fungitoxic substances soon attains a level inhibitory to the invading organism. Pronounced inhibition of germ tube growth in some treatments in relation to spore germination seemed to be of particular significance when such toxicity is confined relating to disease resistance as a post-interaction phenomenon. Seed treatment interfered with infection process itself, since barium and mercuric chloride induced significant reductions in the number of lesions, and as well as mean lesion size implying appreciable inhibition of lesion number was less pronounced but that on lesion size appeared to be greater for most of the treatments where plants exhibited proportionately more small lesions and fewer large lesions as compared with controls. These results coincided with earlier findings with Vigna mungo. (Bhajbhuje, 2014).

The symptom expression was significantly inhibited at 2-3wk and moderately at 4-5wk stages in most of the seed treatments. The protective effect of seed treatment was persisted in 6-wk-old plants but it was declined by $5-8 \%$ over 5 -wk-old plants with all the treatment. This may be quite possible that production of phytoalexin-like substances was initially stimulated and detected in young seedlings but at later stages, there may be insufficient quantity of accumulation of phytoalexins-like substances by little aged seedlings (Eckadt, 2011) or applied chemicals may have been metabolized in host tissues and their concentrate probably were diluted by seedling growth so as to leave little toxic effect at later stages (Bhajbhuje, 2014). It seems unlikely that as the chlorides of mercury and barium had their direct toxic effect on the pathogen but these test chemicals have provided substantial protection to Sorghum vulgare $L$ seedlings; it was in all probability an induced effect. Pronounced production of fungitoxic substance in the treated plants in different treatments when inoculated may induced moderate to high level of fungitoxicity as compared to little or mild toxicity developed in untreated plants and relationship between such post infection levels of toxicity in treated plants and levels of resistance induced in such stimulated high post-infection productions of fungitoxic substances in susceptible tissue may be due to a conditioning effect of treatment chemicals which make plant resistant and readily respond to infection by producing large amount of fungitoxic substances (Eckadt, 2011; Bhajbhuje, 2013). As the conditioning effect wakens with time, the production of extra fungitoxic substances diminishes and the induced protective effect also declines.

The salts of heavy metals, a known phytoalexin inducer chemicals, were used at dilute concentration (10-4) for wet seed treatment, most of the six heavy metal salts tested appeared to provide moderate to substantial protection to Sorghum seedlings against Helminthosporium leaf spot infection, resulting from both artificial inoculation and natural infection with virulent pathogen. This indicated successful induction of resistance in susceptible plants by treatment with such chemicals which often persisted at appreciable levels even up to 5-6-wk. growth stage. The wet seed treatment of chemicals seemed to be the most effective type of treatment, provided substantial and long persistence protection to significant level. Although apparent enhanced post-infection production of fungitoxic substance(s) was strong in Sorghum vulgare L. also some antifungals and phenol have been reported (Lucy and Ifedayo, 2012); however synthesis and accumulation of efficient phytoalexin has not so far been reported against infection of leaf spot causing pathogen, any suggestion about the possible involvement of such compounds in the development of resistance in them is conjectural. Nevertheless, an involvement of some kind of fungitoxic substance in this process is strongly indicated.

It is revealed that Since phytoalexin inducer may act as sensitizers, normally remain suppressed in compatible host pathogen interactions and activate the dynamic defense potential of the host and may induced series of changes in the process of metabolism of the susceptible host; appear to modify the hostparasite interactions in such a way as to result in inhibition of symptom development and an expression of host resistance. 
Table :1: Effects of wet seed treatment with heavy metal salts on symptom expression in pot- grown uninoculated Sorghum vulgare L. seedlings at different intervals ${ }^{1}$.

\begin{tabular}{|c|c|c|c|c|c|c|c|}
\hline \multirow[b]{3}{*}{ Chemicals } & \multirow[b]{3}{*}{$\begin{array}{l}\text { Conc. } \\
\text { (M) }\end{array}$} & \multicolumn{6}{|c|}{ Disease symptoms of uninoculated seedlings ${ }^{2}$ (Age of the plant) } \\
\hline & & \multicolumn{2}{|c|}{2 -weeks } & \multicolumn{2}{|c|}{3 -weeks } & \multicolumn{2}{|c|}{4 -weeks } \\
\hline & & $\begin{array}{l}\text { Mean no. of } \\
\text { Lesions / } \\
\text { plant }\end{array}$ & $\begin{array}{c}\text { Mean } \\
\text { disease } \\
\text { index/plant }\end{array}$ & $\begin{array}{l}\text { Mean no. } \\
\text { of } \\
\text { Lesions/ } \\
\text { plant }\end{array}$ & $\begin{array}{c}\text { Mean } \\
\text { disease } \\
\text { index/plant }\end{array}$ & $\begin{array}{l}\text { Mean } \\
\text { no. of } \\
\text { Lesions } \\
\text { / plant }\end{array}$ & $\begin{array}{c}\text { Mean } \\
\text { disease } \\
\text { index/ } \\
\text { plant }\end{array}$ \\
\hline $\begin{array}{l}\text { Water } \\
\text { (Control) }\end{array}$ & & 34 & 18.8 & 40 & 22.2 & 46 & 25.6 \\
\hline $\begin{array}{l}\text { Mercuric } \\
\text { chloride }\end{array}$ & $10^{-4}$ & $\begin{array}{l}07 \\
(-79.4)^{3}\end{array}$ & $\begin{array}{l}2.2 \\
(-88.3)\end{array}$ & $\begin{array}{l}08 \\
(-80.0)\end{array}$ & $\begin{array}{l}4.3 \\
(-80.6)\end{array}$ & $\begin{array}{l}14 \\
(-69.6) \\
\end{array}$ & $\begin{array}{l}7.0 \\
(-73.7) \\
\end{array}$ \\
\hline $\begin{array}{l}\text { Cupric } \\
\text { chloride }\end{array}$ & $10^{-4}$ & $\begin{array}{l}10 \\
(-70.6)\end{array}$ & $\begin{array}{l}2.7 \\
(-85.6)\end{array}$ & $\begin{array}{l}10 \\
(-75.0)\end{array}$ & $\begin{array}{l}4.8 \\
(-78.4)\end{array}$ & $\begin{array}{l}15 \\
(-67.4)\end{array}$ & $\begin{array}{l}8.2 \\
(-67.9)\end{array}$ \\
\hline $\begin{array}{l}\text { Barium } \\
\text { chloride }\end{array}$ & $10^{-4}$ & $\begin{array}{l}13 \\
(-61.8)\end{array}$ & $\begin{array}{l}6.3 \\
(-66.5)\end{array}$ & $\begin{array}{l}08 \\
(-80.0)\end{array}$ & $\begin{array}{l}3.5 \\
(-84.2)\end{array}$ & $\begin{array}{l}13 \\
(-71.7)\end{array}$ & $\begin{array}{l}5.9 \\
(-76.9)\end{array}$ \\
\hline $\begin{array}{l}\text { Ferric } \\
\text { chloride }\end{array}$ & $10^{-4}$ & $\begin{array}{l}19 \\
(-44.1)\end{array}$ & $\begin{array}{l}9.8 \\
(-47.9) \\
\end{array}$ & $\begin{array}{l}23 \\
(-42.2)\end{array}$ & $\begin{array}{l}10.9 \\
(-49.1)\end{array}$ & $\begin{array}{l}23 \\
(-50.0)\end{array}$ & $\begin{array}{l}11.9 \\
(-53.5)\end{array}$ \\
\hline $\begin{array}{l}\text { Cadmium } \\
\text { chloride }\end{array}$ & $10^{-4}$ & $\begin{array}{l}11 \\
(-67.6)\end{array}$ & $\begin{array}{l}4.4 \\
(-76.6)\end{array}$ & $\begin{array}{l}12 \\
(-70.0)\end{array}$ & $\begin{array}{l}4.1 \\
(-81.5)\end{array}$ & $\begin{array}{l}17 \\
(-63.4)\end{array}$ & $\begin{array}{l}8.8 \\
(-65.6)\end{array}$ \\
\hline $\begin{array}{l}\text { Lithium } \\
\text { sulphate }\end{array}$ & $10^{-4}$ & $\begin{array}{l}14 \\
(-41.2)\end{array}$ & $\begin{array}{l}7.3 \\
(-61.2) \\
\end{array}$ & $\begin{array}{l}18 \\
(-55.0) \\
\end{array}$ & $\begin{array}{l}9.5 \\
(-57.2)\end{array}$ & $\begin{array}{l}26 \\
(-43.8) \\
\end{array}$ & $\begin{array}{l}13.4 \\
(-47.7) \\
\end{array}$ \\
\hline \multicolumn{8}{|c|}{ 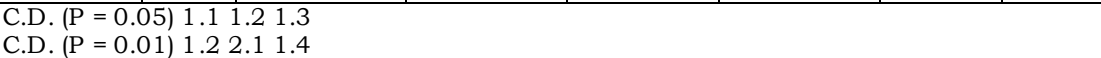 } \\
\hline
\end{tabular}

Table 2: (a) Effect of wet seed treatment with chemicals on symptom expression on pot-grown seedlings inoculated with Helminthosporium turcicum after $3 \& 4$-weeks (b) Fungitoxic effect of leaf diffusates of wet seed treated seedlings of Sorghum vulgare L. (both uninoculated and inoculated) on spore germination and germ tube growth

\begin{tabular}{|c|c|c|c|c|c|c|c|c|c|c|c|c|c|c|}
\hline \multirow[b]{4}{*}{ Chemicals } & \multicolumn{10}{|c|}{$\begin{array}{c}\text { Germination of spores }(\%) \text { and germ tube growth }(\mu \mathrm{m}) \text { in leaf diffusates }{ }^{3} \\
\text { Age of the plant (weeks) }\end{array}$} & \multicolumn{4}{|c|}{$\begin{array}{l}\text { Disease symptoms } \\
\text { Age of the plant (weeks) }\end{array}$} \\
\hline & \multirow{2}{*}{\multicolumn{2}{|c|}{$\frac{2 \text {-weeks }}{\text { Uninoculated }}$}} & \multicolumn{4}{|c|}{ 3-weeks } & \multicolumn{4}{|c|}{ 4-weeks } & \multirow{2}{*}{\multicolumn{2}{|c|}{$\begin{array}{c}5 \text {-week } \\
\text { Inoculated }\end{array}$}} & \multirow{2}{*}{\multicolumn{2}{|c|}{$\begin{array}{c}\text { 6-week } \\
\text { Inoculated }\end{array}$}} \\
\hline & & & \multicolumn{2}{|c|}{ Uninoculated } & \multicolumn{2}{|c|}{ Inoculated } & \multicolumn{2}{|c|}{ Uninoculated } & \multicolumn{2}{|c|}{ Inoculated } & & & & \\
\hline & $\begin{array}{c}\text { Germi } \\
\text { nation } 4 \\
(\%)\end{array}$ & $\begin{array}{l}\text { Mean } \\
\text { germ } \\
\text { tube } \\
\text { length5 }\end{array}$ & $\begin{array}{c}\text { Germina } \\
\text { tion }(\%)\end{array}$ & \begin{tabular}{|l|} 
Mean \\
germ \\
tube \\
length
\end{tabular} & $\begin{array}{l}\text { Germina } \\
\text { tion }(\%)\end{array}$ & $\begin{array}{l}\text { Mean } \\
\text { germ } \\
\text { tube } \\
\text { length }\end{array}$ & $\begin{array}{c}\text { Germi } \\
\text { nation } \\
(\%)\end{array}$ & $\begin{array}{l}\text { Mean } \\
\text { germ } \\
\text { tube } \\
\text { length }\end{array}$ & $\begin{array}{c}\text { Germi } \\
\text { nation } \\
(\%)\end{array}$ & $\begin{array}{l}\text { Mean } \\
\text { germ } \\
\text { tube } \\
\text { length }\end{array}$ & $\begin{array}{c}\text { Mean } \\
\text { no. of } \\
\text { lesions } \\
\text { /plant }\end{array}$ & \begin{tabular}{|c|} 
Mean \\
disease \\
index \\
/plant
\end{tabular} & \begin{tabular}{|c|} 
Mean \\
no. of \\
lesions \\
/plant
\end{tabular} & $\begin{array}{c}\text { Mean } \\
\text { disease } \\
\text { index } \\
\text { / plant }\end{array}$ \\
\hline $\begin{array}{l}\text { Water } \\
\text { (Control) }\end{array}$ & 94 & 104 & 99 & 128 & $\begin{array}{l}88 \\
(-11.1)\end{array}$ & $\begin{array}{l}107 \\
(-16.4)\end{array}$ & 102 & 136 & $\begin{array}{l}93 \\
(-8.8)\end{array}$ & $\begin{array}{l}123 \\
(-9.6)\end{array}$ & 48 & 22.5 & 53 & 26.8 \\
\hline $\begin{array}{l}\text { Mercuric } \\
\text { chloride }\end{array}$ & \begin{tabular}{|l|l|}
39 \\
$(-58.5)^{1}$
\end{tabular} & $\begin{array}{l}41 \\
(-60.0)\end{array}$ & $\begin{array}{l}53 \\
(-46.5)^{1}\end{array}$ & $\begin{array}{l}59 \\
(-53.9)\end{array}$ & $\begin{array}{ll}18 \\
(-81.8)\end{array}$ & $\begin{array}{ll}22 \\
(-82.8)\end{array}$ & $\begin{array}{l}98 \\
(-3.9)\end{array}$ & $\begin{array}{l}133 \\
(-2.2)\end{array}$ & $\begin{array}{l}26 \\
(-74.5)\end{array}$ & \begin{tabular}{|l}
6 \\
$(-73.5)$
\end{tabular} & \begin{tabular}{|l|}
14 \\
$(-70.8)^{1}$
\end{tabular} & \begin{tabular}{|l}
6.9 \\
$(-69.3)$
\end{tabular} & \begin{tabular}{|l|}
24 \\
$(-54.7)$
\end{tabular} & $\begin{array}{l}11.7 \\
(-56.3)\end{array}$ \\
\hline $\begin{array}{l}\text { Cupric } \\
\text { chloride }\end{array}$ & \begin{tabular}{|l|}
41 \\
$(-55.4)$
\end{tabular} & \begin{tabular}{|l|}
43 \\
$(-58.7)$
\end{tabular} & $\begin{array}{l}59 \\
(-40.4)\end{array}$ & \begin{tabular}{|l|}
66 \\
$(-48.4)$
\end{tabular} & $\begin{array}{l}21 \\
(-78.8)\end{array}$ & \begin{tabular}{|l|}
28 \\
$(-78.1)$
\end{tabular} & $\begin{array}{l}97 \\
(-4.9)\end{array}$ & $\begin{array}{l}131 \\
(-3.7)\end{array}$ & $\begin{array}{l}30 \\
(-70.6)\end{array}$ & $\begin{array}{l}41 \\
(-69.8)\end{array}$ & \begin{tabular}{|l|}
17 \\
$(-64.6)$
\end{tabular} & \begin{tabular}{|l}
8.2 \\
$(-63.6)$
\end{tabular} & \begin{tabular}{|l|}
6 \\
$(-50.9)$
\end{tabular} & $\begin{array}{l}12.2 \\
(-54.8)\end{array}$ \\
\hline $\begin{array}{l}\text { Barium } \\
\text { chloride }\end{array}$ & $\begin{array}{l}50 \\
(-46.8)\end{array}$ & \begin{tabular}{|l}
46 \\
$(-55.8)$
\end{tabular} & \begin{tabular}{|l|}
55 \\
$(-44.4)$
\end{tabular} & $\begin{array}{l}69 \\
(-46.1)\end{array}$ & $\begin{array}{l}19 \\
(-80.8)\end{array}$ & \begin{tabular}{|l|}
26 \\
$(-79.7)$
\end{tabular} & $\begin{array}{l}98 \\
(-3.9)\end{array}$ & $\begin{array}{l}34 \\
(-1.5)\end{array}$ & $\begin{array}{l}28 \\
(-72.5)\end{array}$ & $\begin{array}{l}38 \\
(-72.1)\end{array}$ & \begin{tabular}{|l|}
12 \\
$(-75.0)$
\end{tabular} & \begin{tabular}{|l|}
5.5 \\
$(-75.6)$
\end{tabular} & $\begin{array}{l}23 \\
(-56.6)\end{array}$ & $\begin{array}{l}11.1 \\
(-58.6)\end{array}$ \\
\hline $\begin{array}{l}\text { Ferric } \\
\text { chloride }\end{array}$ & $\begin{array}{l}47 \\
(-50.0)\end{array}$ & \begin{tabular}{|l|}
49 \\
$(-52.9)$
\end{tabular} & $\begin{array}{l}61 \\
(-38.4)\end{array}$ & $\begin{array}{l}73 \\
(-43.0)\end{array}$ & $\begin{array}{l}24 \\
(-75.8)\end{array}$ & \begin{tabular}{|l|}
33 \\
$(-74.2)$
\end{tabular} & $\begin{array}{l}97 \\
(-4.9)\end{array}$ & $\begin{array}{l}129 \\
(-5.1)\end{array}$ & \begin{tabular}{|l}
33 \\
$(-67.6)$
\end{tabular} & $\begin{array}{l}43 \\
(-68.4)\end{array}$ & \begin{tabular}{|l|}
19 \\
$(-60.4)$
\end{tabular} & $\begin{array}{l}9.7 \\
(-56.9)\end{array}$ & \begin{tabular}{|l|}
29 \\
$(-45.3)$
\end{tabular} & $\begin{array}{l}13.6 \\
(-49.3)\end{array}$ \\
\hline $\begin{array}{l}\text { Cadmium } \\
\text { chloride }\end{array}$ & $\begin{array}{l}43 \\
(-54.3)\end{array}$ & \begin{tabular}{|l}
44 \\
$(-58.0)$
\end{tabular} & $\begin{array}{l}54 \\
(-45.5)\end{array}$ & $\begin{array}{l}68 \\
(-46.9)\end{array}$ & $\begin{array}{l}33 \\
(-66.7)\end{array}$ & $\begin{array}{l}38 \\
(-70.3)\end{array}$ & $\begin{array}{l}96 \\
(-5.9)\end{array}$ & $\begin{array}{l}33 \\
(-2.2)\end{array}$ & $\begin{array}{l}41 \\
(-59.8)\end{array}$ & $\begin{array}{l}53 \\
(-61.0)\end{array}$ & $\begin{array}{l}22 \\
(-54.2)\end{array}$ & $\begin{array}{l}10.8 \\
(-52.0)\end{array}$ & $\begin{array}{l}29 \\
(-45.3)\end{array}$ & $\begin{array}{l}14.4 \\
(-46.3)\end{array}$ \\
\hline $\begin{array}{l}\text { Lithium } \\
\text { sulphate }\end{array}$ & $\begin{array}{l}49 \\
(-47.9)\end{array}$ & \begin{tabular}{|l|}
63 \\
$(-39.4)$
\end{tabular} & $\begin{array}{l}64 \\
(-35.4)\end{array}$ & $\begin{array}{l}78 \\
(-39.1)\end{array}$ & \begin{tabular}{|l|}
35 \\
$(-64.6)$
\end{tabular} & $\begin{array}{l}48 \\
(-62.5)\end{array}$ & $\begin{array}{l}97 \\
(-4.9)\end{array}$ & $\begin{array}{l}134 \\
(-1.5)\end{array}$ & $\begin{array}{l}63 \\
(-38.2)\end{array}$ & $\begin{array}{l}74 \\
(-45.6)\end{array}$ & \begin{tabular}{|l|}
28 \\
$(-41.7)$
\end{tabular} & \begin{tabular}{|l|}
3.9 \\
$(-38.2)$
\end{tabular} & \begin{tabular}{|l|}
37 \\
$(-30.2)$
\end{tabular} & $\begin{array}{l}18.2 \\
(-32.1)\end{array}$ \\
\hline \multicolumn{15}{|c|}{ 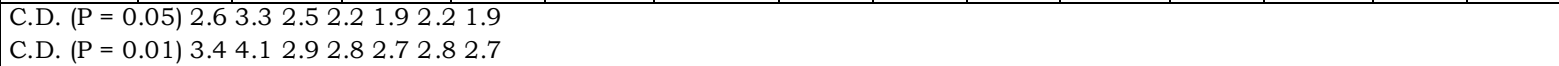 } \\
\hline \multicolumn{15}{|c|}{$\begin{array}{l}\text { 1. Values in parenthesis indicate percentage reduction or increase in terms of uninoculated control. } \\
\text { 2. Aqueous solutions of all the heavy metal salts were tested at } 10^{-4} \mathrm{M} \text { conc. } \\
\text { 3. Following inoculation, leaf diffusates were collected from both uninoculated (healthy) and inoculated plants after } 3 \text { days. } \\
\text { 4. Average of } 300 \text { spores } \mathbf{5} \text {.Avg. of } 90 \text { germlings. }\end{array}$} \\
\hline
\end{tabular}

\section{Conclusion:}

An aqueous solution at dilute conc of salts of heavy metals applied by wet seed treatment, induced significant reduction in infection and provided considerable to moderate protection to Sorghum vulgare L. seedlings, at different stages against artificial inoculation with a leaf spot causing virulent pathogen, Helminthosporium turcicum The experimental findings revealed that seed soaking in aqueous dilute solutions of chlorides of mercury, and barium to test condition provided a more vigorous defiance response to virulent pathogen 
as well as induced long persistent substantial protection at significant level. These phytoalexin inducer chemicals serve as very promising compounds for use in plant disease control. Wet seed treatment proved to be the most effective in seed producing plants.

\section{Acknowledgement:}

The author gratefully acknowledges the facilitation of this work by Dr .R.P. Thakre, ExProfessor \& Mycologist and Prof. \& Head, P.G. Deptt. of Botany, RTM, Nagpur University, Nagpur.

\section{References:}

Amil-Ruiz, F., Blanco-Portales, R., MunozBlanco, J. and Caballero, J. L. (2011): The strawberry plant defense mechanism: A molecular review. Plant Cell Physiol., 52 (11) : 1873-1903.

Ashraf, A. and Ali, T.A. (2007): Effect of heavy metals on soil microbial community and mung beans seed germination. Pak. J. Bot., 39(2): 629636.

Atkinson, N.J. and Urwin, P.E (2012): The interaction of plant biotic and abiotic stresses: from gene to field. Journal of Experimental Botany, 63(3): 1-21

Ballhom, D.J., Kautz, S., Heil, M., Hegeman, A.D. (2009): Cyanogenesis of wild lima bean (Phaseolus lunatus L.) is an efficient direct defence in nature. Plant Singhing and Behavior 4(8): 735-745.]

Bhajbhuje, M.N. (2013): Role of heavy metal salts on susceptibility of Solanum melongena L. seedlings to Alternaria early blight disease. Int. $J$. of Life Sciences 1 (1):51-62.

Bhajbhuje, M.N. 2014. Role of heavy metal salts in protection of Vigna mungo (L.) Hepper seedlings against Alternaria leaf spot infection by seed treatment. Int. Jour Res in Biosci, Agric \& Technology, 2(2) : 23-33.

Bhattu, G., Ch.K.V.L., Male, S.N.A., Priya, T.H., Malleswar and Reeshma, S.K. (2011): A Phytopharmacological review of Vigna species. Pharmanest, 2(1) : 61-67.

Caballero J.L. (2011): The strawberry plant defence mechanism: A molecular review. Plant $\&$ Cell Physiology,

52 (11): 1873-1903.
CMI. (2010): Commonwealth Mycological Institute. Description of Pathogenic fungi and bacteria.

Kew Surey, England. Pp 451-460.

Eckadt, N.A. (2011): Induction of Phytoalexin Biosynthesis: WRKY 33 - Is a Target of MAPK Singling. Plant Cell, 23(4) : 1190.

Feofilova, E., Ivashechkin, A., Alekhin, A. and Sergemma, Y. (2012): Fungal spores: Dormancy, germination, chemical composition and role in biotechnology (review) Appl Biochem, \& Microbiol., 48(1): 1

Iriti, M. and Franco, F. (2009): Chemical Diversity and Defence Metabolism: How Plant Cope with pathogen

and ozone pollution. Int. J. Mol. Sci., 10 : 337339

Karthikeyan., G, Doraisamy and Rabindran, $\mathbf{R}$ (2009): Induction of systemic resistance in blackgram (Vigna mungo) against urdbean leaf crinckle virus by chemicals. Archives of Phytopathology and Plant protection, 42(1): 1-8

Kobayashi, F., Ishida, K., Ikeura, H., Okakei, S and Hayata, Y. (2012): Application of tomato (Solanum lycopersicum ) leaf volatiles as antifungal agent against plant pathogenic fungi. Journal of

Agricultural Science, 4(8) : 231-235.

Mazid, M., Khan, T.A and Mohammad, F. (2011): Role of secondary metabolites in defence mechanism of plants. Biol. \& Medicine, 3(2) : 232-249

Mert-Turk, F. (2002): Phytoalexin: Defence or just a response to stress? J. Cell \& Mol. Biol., 1 : 1-6.

Lucy, O.F. and Ifedayo, O.A. (2012) Guinea Corn (Sorghum vulgare L.) leaf, a potential source of nutrients and phytochemicals. Food and Public Health, 2(6) : 228-230

Raju, S., Jayalaxmi, S.K., Sreeramulu, K. (2008): Comparative study on the induction of defence related enzymes in two cultivars of chickpea (Cicer arietinum L.) genotype by salicylic acid spermine and Fusarium oxysporum f. sp. Cicero. Australian Jour. Crop Sci., 2(3): 121-140. 
Savithasuri (2013): Ayurveda, medicinal properties and health benefits of black gramVigna mungo.

http:/ / www/ayurhelp.com/plants / blackgram (Retrieved on March 20, 201).

Sobolev, V., Guo, B. and Robert, H. (2007): Interrelationship of Phytoalexin Production and Disease Resistance in Selected Peanut Genotypes. J. Agric. and Food Chem., 55 : 2195-2200.

Trivedi A, Sharma Sandeep $\mathbf{K}$, Hussain $\mathbf{T}$, Sharma SK, Gupta PK. (2013): Application of biodynamic preparation, bio-control agent and botanicals for organic management of virus and leaf spots of black gram (Vigna mungo L. Hepper). Acad. J. Agric. Res., 1(4): 60-64.

Wikipedia (2015).: Sorghum vulgare L.Wikimedia Foundation, Org. en.wikipedia,org/wiki. Inc .

(Retrieved on March 20, 2015).

Zhuang X, K.E. McPhee, T.E. Coram, T.L. Peever and Chilvers, M.I. (2012): Rapid transcriptome

characterization and parsing of sequences in non-model host-pathogen interaction; pea Sclerotinia

sclerotiorum. BMC Genomics 13 : 668. Pp 1-19. 